\title{
Developing Performance Assessment Instruments For Local Organizations in Ecological Restoration As Part of The Cross-Cutting Capacity Development (CCCD-UNDP) Project In Indonesia
}

\author{
Mangku Purnomo* \\ Department of Socio-Economics, Faculty of Agriculture, University of Brawijaya, Jl. Veteran, Malang \\ 65145, Indonesia
}

Received: 27 September 2021; Revised: 6 October 2021; Accepted: 25 October 2021

\begin{abstract}
Using the CCCD project as the locus of study, this paper reconstructs the empowerment process to reveal and arrange the instruments used at each empowerment stage. The performance measurement instrument was used to measure whether the organization involved in the project was related to project activities directly or indirectly. These two activities helped us compile criteria for the various organizations involved and conceptually draw the pattern of organizational relationships. Findings showed three main processes: (1) the process of identifying and selecting organizations, (2) the process of mentoring and facilitation, and (3) the process of evaluation and follow-up plan. The organizations or groups were divided into primary, secondary, and tertiary groups. Primary groups were directly related and involved in the project. Secondary groups could be involved and did not depend on funding and assistants. Tertiary groups did not need to be involved unless they had such political consequences to influence other groups. The group itself took part in decision-making about management patterns. The pattern could not be separated from the dynamics of policies, markets, and local village and supra-village politics. Based on these findings, the CCCD project confirms that a group empowerment approach must focus on the substantive aspect of achieving project goals, while the procedural aspect merely supports the administrative arrangement so objectives can be achieved more efficiently.
\end{abstract}

Keywords: empowerment; local groups; conservation, decertification; ecology

\section{How to cite:}

Purnomo, M. (2021). Developing Performance Assessment Instruments For Local Organizations in Ecological Restoration As Part of The Cross-Cutting Capacity Development ( CCCD-UNDP ) Project In Indonesia. HABITAT, 32(3), 184-205. https://doi.org/10.21776/ub.habitat.2021.032.3.20

\section{Introduction}

Decreasing biodiversity, food insecurity, natural disasters, and climate change have been a concern of the world community because they threaten our sustainability. The response to these conditions is in The Rio Convention, or known as the United Nations Convention on Biological Diversity (CBD), with objectives of inhibiting the high rate of land degradation, tackling climate change, and preserving bio-diversity, is the international response to the current global problems. Indonesia is also facing the same threats - as such, sustainability has become one of the most critical issues in national development. Indonesia has also been implementing CBD measures seriously-one of the efforts is

*Correspondence Author.

E-mail:mangku@ub.ac.id developing an Integrated Watershed Management Plan (Rencana Pengelolaan DAS Terpadu RPDAST).

Although the program's name is the Integrated Watershed Management Plan, its implementation has neither been consolidated among responsible government institutions nor become a comprehensive policy. Instead, it is sporadic by some government institutions. There has been no reliable watershed management plan to be implemented or replicated in regions throughout Indonesia. Policies on managing natural resources have not been aligned between the provincial, regency/municipal, district, and village governments. At the provincial level, policies on natural resource management revolve around (a) mapping and making quality standards for river water, (b) giving permits for water resource exploitation with minimum efforts for water resource preservation, and (c) giving 
permits for forestry business. The focus is on reforestation efforts with a minimum number of qualified officials at the regency and municipality level. The existing regulations open up room for natural resource management at the village level, yet they neglect preservation. As such, the management of natural resources has led to environmental damage.

In addition to the wrong regulation objects, the process and context of the policy are often not well arranged - the result is no connection between plans and implementation. Policies related to sustainable natural resource management are still tentative and lack coordination between responsible parties. Community involvement is also minimal that reduces the effectiveness of natural resource management programs. Because of unintegrated policies and management in natural resource management, exploitation continues at a very alarming rate. Sand mining, animal hunting, water resource exploitation, utilization of protected areas for economic, tourism, and agriculture activities are some examples of irresponsible natural resource management. Each government institution seems to work on its own when conserving natural resources with the principal objective of showing its superiority in natural resource management over other institutions.

On the other hand, it is impossible to build effective policies without collaboration within one conservation area because activities in such areas are interrelated. In addition, there has been a lack of awareness that a policy will be effective if it substantively follows the social conditions of the community and the characteristics of natural resources (Fletcher, 2017; Purnomo, 2011). Continuous planning and harmonious regulations are the keys to sustainable resource management planning (Panya, Poboon, Phoochinda, and Teungfung, 2018; Purnomo et al., 2010). Therefore, through the Ministry of Environment and Forestry, the government of Indonesia has initiated the Capacity Development Program for Implementing Rio Conventions by Enhancing Incentive Mechanisms for Sustainable Watershed and Land Management Project. The project is funded by the United Nations Development Programme (UNDP). The cross-cutting project bridges three conventions of the United Nations: (1) United Nations Convention on Biological Diversity (UNCBD), (2) United Nations Framework and Convention on Climate Change (UNFCCC), and (3) United Nation Convention to Combat Desertification (UNCCD).
CCCD has been developed since the beginning of 2018 as one of the efforts to deal with natural resource management under UNDP supervision. In Indonesia, project located in two micro watershed that are the Way Khilau Micro Watershed Model (Lampung) and the Sumberbulu Micro Watershed Model (East Java). The program is designed with a social approach at the site level to overcome various coordination barriers. The approach is also used to improve the less focused approach carried out so far, mainly to tackle the difficulty of coordination between sectors and institutions. This site-level approach is expected to target real technical and social problems directly, so the programs implemented can significantly impact the community. This paper reconstructs the empowerment process by using the two pilot projects as the locus of study to reveal and arrange the instruments used at each empowerment stage. After the instrument was structured, the organizational performance measurement instrument was used to measure the performance of the organizations involved in the project. Based on these two activities, we compiled criteria for the various organizations involved and conceptually drew the pattern of organizational relationships.

\section{Theoretical Underpinning}

The group approach has been very popular since AT Mosher (1969) proposed the progressive village concept. The concept then became the guideline for rural development planners where progressive farmer groups were one of the requirements in addition to other physical development and the introduction of agricultural technology. Progressive farmer groups became one of the success factors of the green revolution as a medium for disseminating agricultural technology and mobilizing community participation (Bulkis, 2018; Oxby, 1983; Barham, 2009). Within this phase, such groups were used as media or objects to convey policies from the central government, so their role was to serve the interests of development programs rather than listen to people's aspirations. The groups were designed in such a way to encourage and sometimes even force their members to apply various innovations such as superior seeds, chemical fertilizers, pest control drugs, and others (Kalra, et al., 2013; Mariono, 2015; Rosset, 2000).

This approach has been empirically beneficial to improve agriculture productivity, including livestock (Rustinsyah, 2019), technology adoption (Mwaura, 2014), marketing 
(Ochieng, 2018), rice production (Abdul-Rahman and Abdulai, 2018), food security (Bulkis et al., 2018), and women's participation (Diiro et al., 2018). However, Chambers (1983) criticized modernization approaches, including the green revolution, by changing the role of groups as a means for people's aspirations to generate participation, not mobilization. The group was not only an agent for the dissemination of technology and mobilization but more as a medium for rural communities to express their aspirations and promote participation, especially the poor. The group became a self-help institution that helped fellow members access technology, capital, and social protection (Dutta, 2015; Hoffmann, et al., 2021).

Following the criticism on the role of the groups, more participative approaches were developed in the next phase. Groups become the mean for the people to express their aspirations and the support for their members. The development also included social movement. The farmer groups became the media to grow community participation, and many models were developed to support such groups. Methods of group identification, need mapping, and participatory planning was developed to ensure that group involvement in a project was not biased towards mobilization. The groups then only became an object of development, like in the green revolution. Likewise, special measures were developed to calculate community participation, both on the number of registered members in the organization and their presence in each project activity and on how their participation evolved (Yao et al., 2020).

Meanwhile, borrowing the concept of institutional performance measurement, one of the approaches used in group effectiveness is measuring leadership performance, organizational structures, organizational culture, and vision and mission. Leadership is vital for a well-developed organization because transformative leadership will make it easier for members to contribute voluntarily (Sing et al., 2019; Muralidharan and Pathak, 2018; Asbari, 2020). The leadership quality of an organization or public institution can be measured through the Servant Leadership Assessment Instrument (SLAI) (Dennis, 2004; Parris and Peachey, 2013). SLAI indicators consist of love, empowerment, vision, humility, and trust. The five indicators are shown in Figure 1.

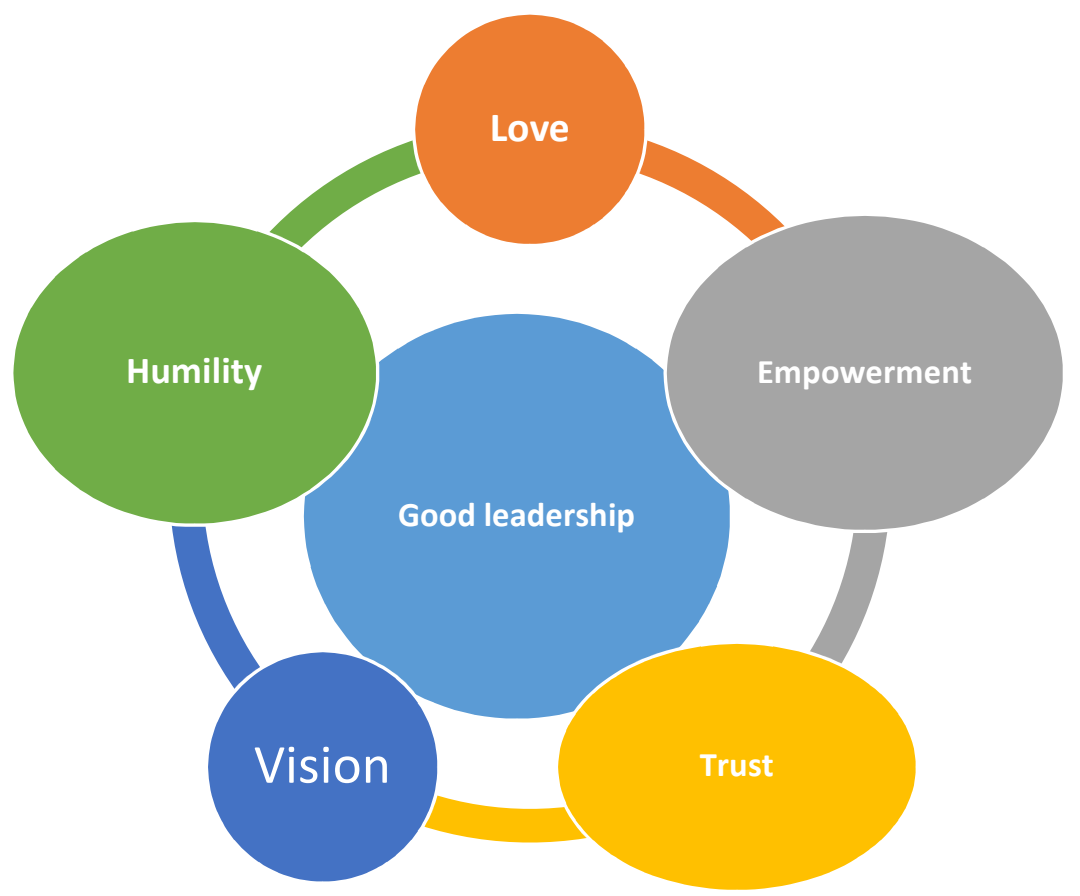

Figure 1. Servant Leadership Indicators (Dennis, 2013)

Organizational performance must also be seen from the completeness of the organizational structure - it means that the organization must have organs to complete all challenges to achieve specific goals. Indicators used to measure an organization's bureaucracy or administrative performance include productivity, service quality, responsiveness, responsibility, and accountability (Spears, 2002; Dwiyanto and Agus, 2006; Barbuto, and Wheeler, 2006). As a core, 
productivity describes the efficiency and effectiveness of services, usually assessed from the ratio between inputs and outputs. Service quality is used to measure people's satisfaction with services, and it can be used as a performance indicator of public organizations. Responsiveness refers to an organization's ability to recognize community needs, set service agendas and priorities, and develop public service programs following community needs and aspirations.
In contrast to responsiveness, which is more outgoing, responsibility explains whether activities of public organizations are carried out following correct administrative principles or organizational policies, both explicitly and implicitly. Finally, public accountability focuses on whether the business processes of public organizations follow good management principles. Figure 2 illustrates how to measure productivity.

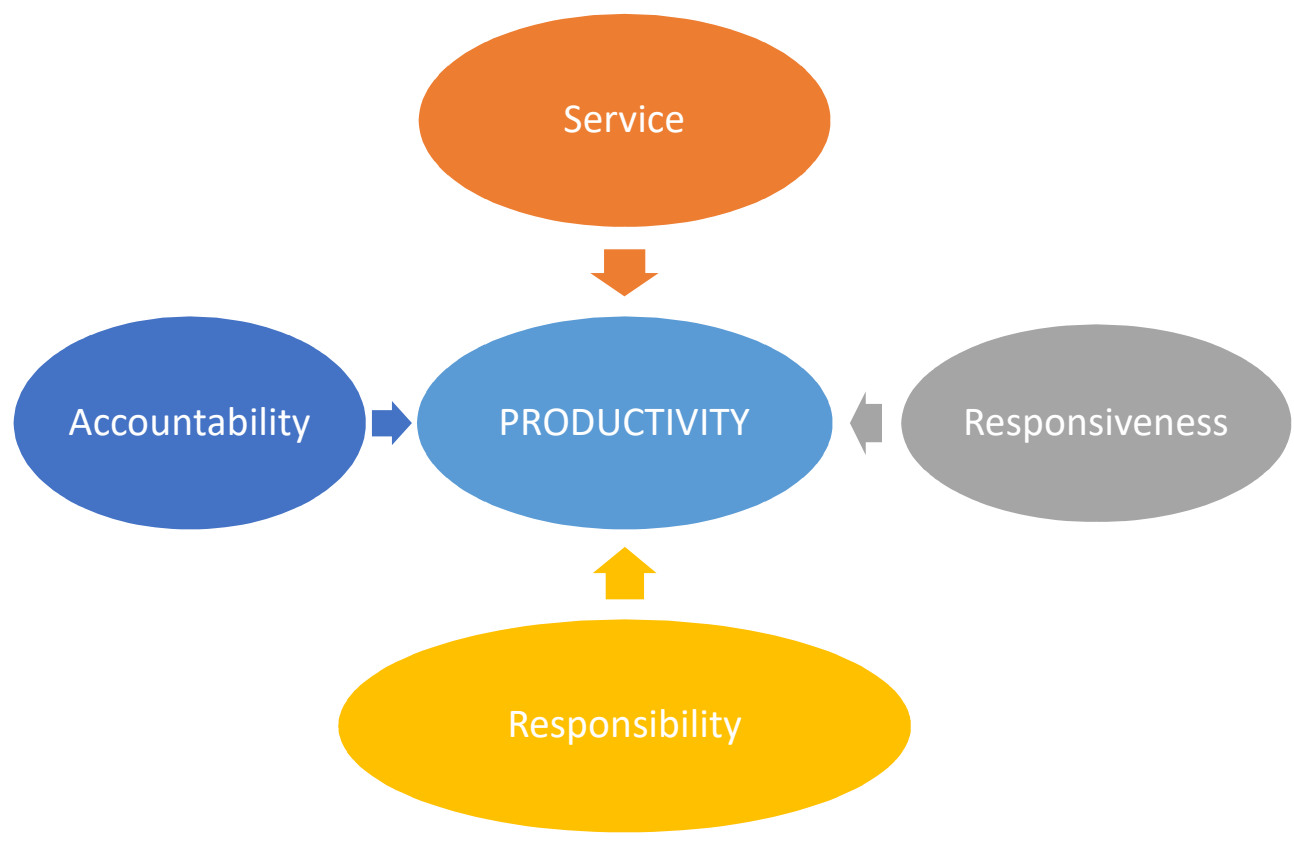

Figure 2. Indicators of Organizational Productivity

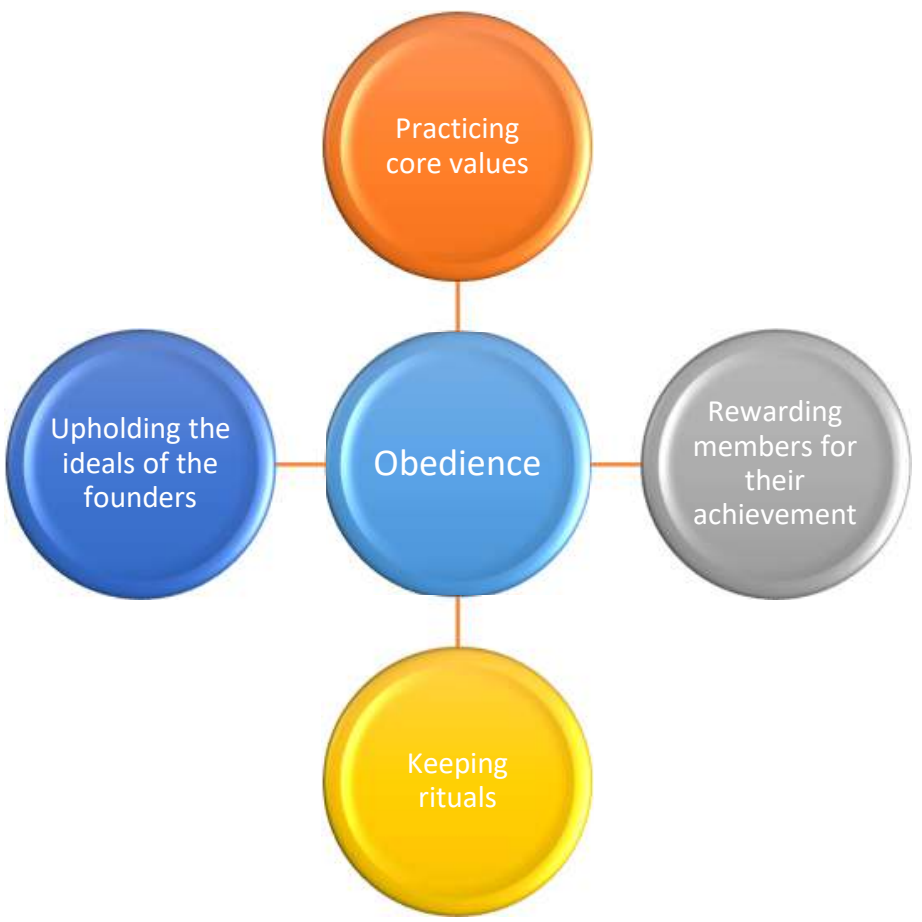

Figure 3. Indicators of Organizational Culture

Available online at HABITAT website: http://www.habitat.ub.ac.id

ISSN: 0853-5167 (p); 2338-2007 (e) 
In addition to good structure, an organization must also have an excellent organizational culture to support its performance. Organizational culture is strong when core values are practiced intensively and shared widely by organization members. A strong organizational culture is present when members show loyalty, obey guidelines for members, live the values, and are rewarded for their achievement. The strong organizational culture is also manifested in rituals and unique characteristics the organization has and in the ideals of the founders. If an organization has a strong culture, it will relatively have good abilities to deal with various changes (Patterson, 2003; Lubis and Hanum, 2020). It will also reduce the control system, which is sometimes expensive (Kalkman and de Waard, 2017). Conceptually the organizational culture is presented in Figure 3.

Assessment of administrative completeness is also crucial because it will be easier to track all transactions and organizational activities to identify weaknesses within organizations. Bookkeeping, for example, affects members' behavior and can encourage greener behavior. Therefore, various records and complete documents will improve organizational performance (Chatelain et al., 2018; do Nascimento, 2021). An organization must at least have five types of documents available: documents on structure, documents on the description of functions, documents of standard operating procedures, and documents of decision making. The farmer groups had such documents, and all members knew and implemented the rules written on those documents.

The last indicator that determines organizational performance is vision and mission in a clear, realistic, and easy-to-remember statement representing the ideals and measurable stages of achievement (Ricard et al., 2009; Wibisono, 2006). The vision and mission must go through three dimensions of growth (formal, dynamic, and motivational) to know their effectiveness (Rey and Bastons, 2018). Based on the description, it can be concluded that organizational performance must be thoroughly assessed, covering leadership, productivity, culture, administrative completeness, and vision and mission. This study would measure the preparation of the organizational assessment instrument for CCCD based on those five aspects. Findings would help determine which organizations should be included and which should not be included further in the program. This vision is closely related to leadership, where vision directs leaders to move the entire staff (Ricard et al., 2009). The more mature an organization, the easier it will be to translate the vision and mission into shared goals of all members within the organization. Thus, vision and mission must be integrally translated into operational definitions by the organization's management (Grossmann et al., 2018).

Based on the elaboration above, the involvement of an organization in project activities such as CCCD must be based on changing the group's paradigm from a medium of mobilization into a medium for channeling aspirations. This view is fully taken into account in compiling organizational assessment instruments. As such, it is expected that participation goes beyond simply being present into voluntary actions based on needs. Likewise, the organizational assessment process must be based on substantive components rather than formality, even though both have the same level of urgency (Yao et al., 2020). Thus, this research used this approach to formulate a group mapping method to choose which groups urgently needed to be involved. Since every program has a limited budget and time constraints, the groups involved must directly support the project goals.

\section{Research Method}

The research areas were deliberately selected at two CCCD project implementation locations, both at the stage of reconstructing the project implementation process and testing leadership quality indicators. Two research locations, namely Bayas Jaya Village, Lampung Province and Bambang Village, East Java Province, have micro watersheds that are threatened with desertification due to climate change. In the first stage, qualitative data were collected and analyzed to explore how the CCCD project worked in group mapping, group assessment, and group selection. We reconstructed the whole process into a systematic stage so group mapping, group assessment, and group selection could be made. We tested the instrument developed on the first stage in the second stage, especially for assessing organizations involved in the CCCD project. The assessment uses a class of 1 to 4 to categorize the previously qualitatively found typologies in depth. The sequential mixed method exploration model, according to Hedren et al., (2018), is as follows: 


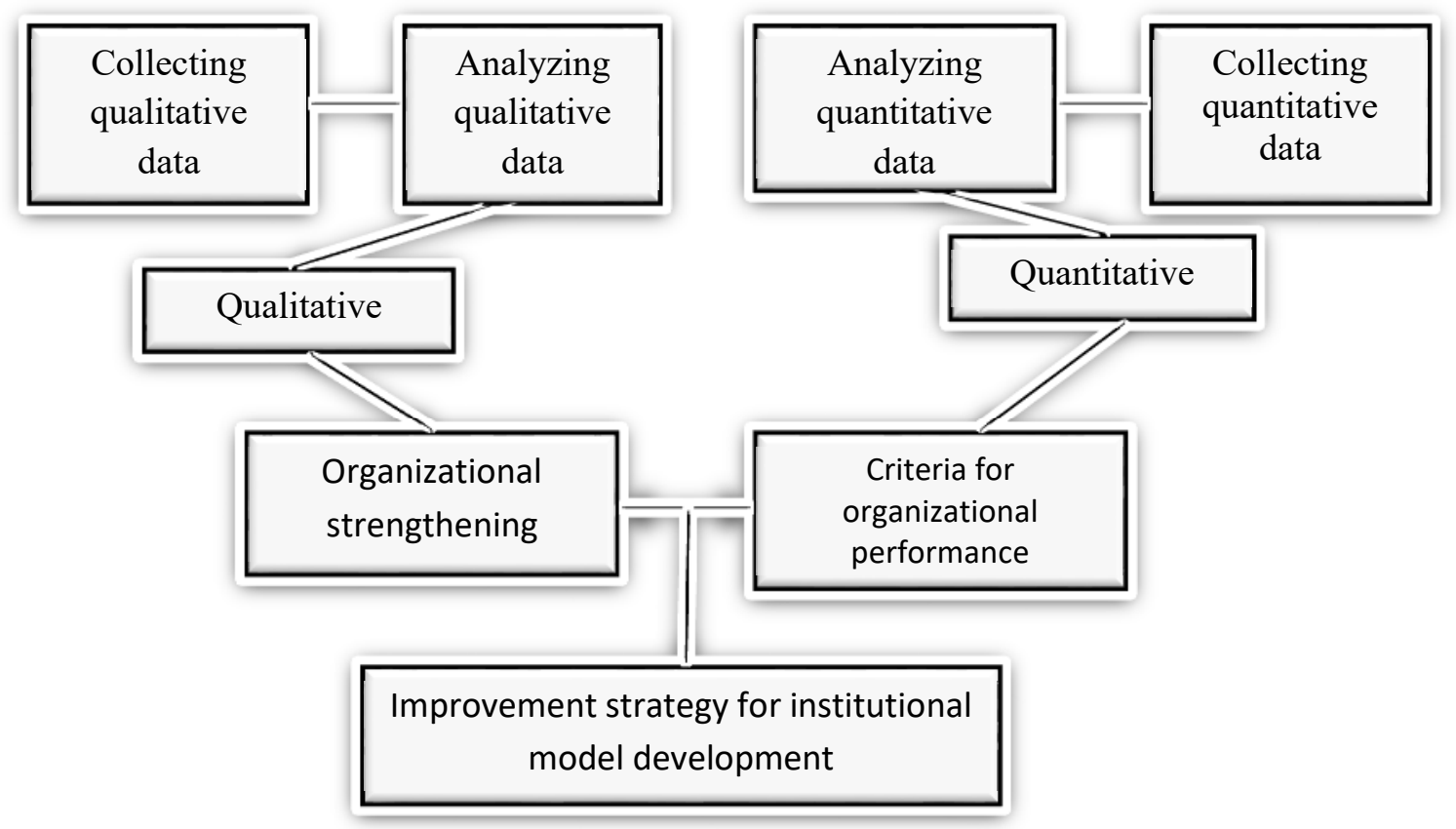

Figure 4. Sequential Flow of Analysis and Exploration

The primary key to getting an objective spectrum of assessment is selecting respondentsthe more complete the parties involved, the more it would reflect the assessment results. We interviewed key informants to strengthen the findings. Our informants included the village head, Kelompok Sadar Wisata (Pokdarwis), tourism managers, and parties involved in CCCD activities. Pokdarwis is an informal organization formed by community members to support tourism development in their area. Before the assessment process, we formulated indicators based on organizational theories verified by observations and project documents. The instrument was then tested on the existing groups to ensure whether the formulated indicators were following the actual conditions or not.

In-depth interviews were conducted by asking some questions orally to reveal and validate the formulated indicators and to enrich the assessment. The interviews were formally structured and unstructured. We also conducted direct observations on events during our study, such as people's behavior, situations, and so forth related to research objectives. The observations in this study were non-participant, which means that we observed participants without actively participating in their activities.

The analytical method used was a mixmethod, a combination of quantitative and qualitative methods. Quantitative methods are used to analyze descriptive statistics to assess mainly group performance. This study used four (4) classes as follows: (a) very low with a score of 1 , (b) low with a score of 2, (c) high with a score of 3 , and (d) very high with a score of 4 . We use these simple statistics because the output of this article would be guidelines for developing local institutions as one of the components against certification within the CCCD project framework. However, findings could be used as an instrument to select groups to be involved in other projects. Thus, CCCD institutional development was the instrument we used to develop the guidelines, but results can be scientifically transferred to other projects.

\section{Results and Discussion}

\section{a. Reconstructing the Process of Group Selection}

The project stages and details are determined administratively in Jakarta as the standard for all implementers. This present study focused more on reconstructing the implementation in the form of social interventions on the project sites. Our findings showed three primary processes: (1) the process of identifying and selecting organizations, (2) the process of mentoring and facilitation, and (3) the process of evaluation and follow-up plan. These three processes represent the aggregation we did, based 
on analysis results on secondary data such as planning documents, activities of project managers and assistants, activities of groups involved in the project, and activities of village officials.

\section{b. The Process of Identifying and Selecting Organizations}

The first and foremost activity within the social interventions was determining the actors involved. It is impossible for a project to conduct peer to peer approach or personal approach, then it uses the group approach to channel people's aspirations. Determining groups or organizations to be involved in a project is crucial since failure to choose the right groups or organizations will result in people's aspirations not being appropriately channeled and low community participation. This process involved three (3) subprocesses: (1) collecting data, (2) mapping the organization's orientation, and (3) selecting organizations. First, data on names of groups or organizations, goals, number of members, and status were collected. The field assistants collected data supervised by the regional or provincial field assistants and Project Management Unit (PMU) in Jakarta. This process collects data on the percentage of community members actively involved in certain groups or organizations. The data become the basis for predicting the social impacts of those active organizations against decision-making by community members. This process also ensures political support and community participation in the future. The respondents chosen by the field assistants were the village heads, community leaders, and village officials. The form used in data collection is presented in Table 1 .

Table 1. Form for Collecting Data about Organizations

\begin{tabular}{|c|c|c|c|c|}
\hline No. & $\begin{array}{c}\text { Name of } \\
\text { Organizations }\end{array}$ & Goals & $\begin{array}{c}\text { Number } \\
\text { of } \\
\text { Members }\end{array}$ & Status \\
\hline 1 & & & & $\begin{array}{l}\text { Active - } \\
\text { Inactive }\end{array}$ \\
\hline 2 & & & & \\
\hline 3 & & & & \\
\hline 4 & & & & \\
\hline 5 & & & & \\
\hline$\ldots$ & & & & \\
\hline
\end{tabular}

Second, we mapped the orientation of organizations. Based on the data from the first stage, we analyzed which organizations had the direct and indirect role in natural resource conservation. This mapping aims to classify organizations into the primary, secondary, and tertiary classes to help project managers determine which organizations must be prioritized in a certain project. For example, even when an organization has many active members but its goals are not directly related to natural resource conservation, then their involvement within the project will be irrelevant. Respondents within this stage included the head of the organization, the administrators, and samples of members. The summary of criteria, aspects, and indicators for mapping is presented in Table 2 .

Table 2. Assessment on the Orientation of Organization

\begin{tabular}{|c|c|c|}
\hline CRITERIA & ASPECTS & INDICATORS \\
\hline \multirow{8}{*}{ Ecology } & Activities bring good impact to the environment & 1. Highly affecting \\
\hline & & 2. Affecting \\
\hline & & 3. Indirectly affecting \\
\hline & & 4. Not affecting \\
\hline & Having the vision to improve the environment & 1. Very considerating \\
\hline & & 2. Considerating \\
\hline & & 3. Ignoring \\
\hline & & 4. Very ignoring \\
\hline \multirow{8}{*}{ Economy } & Being able to improve the economy of the members and & 1. Highly affecting \\
\hline & surrounding communities & 2. Affecting \\
\hline & & 3. Indirectly affecting \\
\hline & & 4. Not affecting \\
\hline & Being able to increase income without damaging natural & 1. Highly affecting \\
\hline & resources & 2. Affecting \\
\hline & & 3. Indirectly affecting \\
\hline & & 4. Not affecting \\
\hline
\end{tabular}


Table 2. Assessment on the Orientation of Organization (advanced)

\begin{tabular}{lll}
\hline CRITERIA & \multicolumn{1}{c}{ ASPECTS } & \multicolumn{1}{c}{ INDICATORS } \\
\hline \multirow{3}{*}{ Sociocultural } & Creating new habits of preserving the environment & 1. Communities \\
& & 2. Members \\
& & 3. Pengurus \\
\multirow{3}{*}{ Gender } & Empowering everyone regardless of their gender & 4. Pengurus inti \\
& & 1. Very considerating \\
& & 2. Considerating \\
& 3. Ignoring \\
\hline
\end{tabular}

Source: Primary data (2020, analyzed)

Those aspects were then written on instruments for data collection used as the guideline by the field assistants. The aspects were given a scale from 1 to 4 , representing their urgency toward the success of the project. We assumed that the deeper the concern an organization had on conservation issues, the bigger its chance of being involved in the next project. The instrument for data collection is presented in Table 3.

Table 3. Form for Collecting Data about Orientation of Organizations

\begin{tabular}{l}
\multicolumn{1}{c}{ QUESTIONS } \\
\cline { 2 - 2 } Do the programs bring impacts to the environment? \\
1. Not affecting \\
2. Indirectly affecting \\
3. Affecting \\
4. Highly affecting \\
\hline In making vision and future projections, does the \\
organization consider ecological restoration or \\
improvement? \\
1. Very ignoring \\
2. Ignoring \\
3. Considerating \\
4. Very considerating \\
\hline Do the programs run by the organization so far \\
bring significant economic impact to its members? \\
1. Not affecting \\
2. Indirectly affecting \\
3. Affecting \\
4. Highly affecting \\
\hline Does economic improvement affect ecological \\
restoration? \\
1. Not affecting \\
2. Indirectly affecting \\
3. Affecting \\
4. Highly affecting \\
\hline Who is involved in efforts to build the habit of \\
preserving the environment? \\
1. Managers \\
2. Administrators \\
3. Members \\
4. Community members \\
Does the organization consider gender equality \\
while running the programs? \\
\hline
\end{tabular}


Table 3. Form for Collecting Data about Orientation of Organizations (advanced)

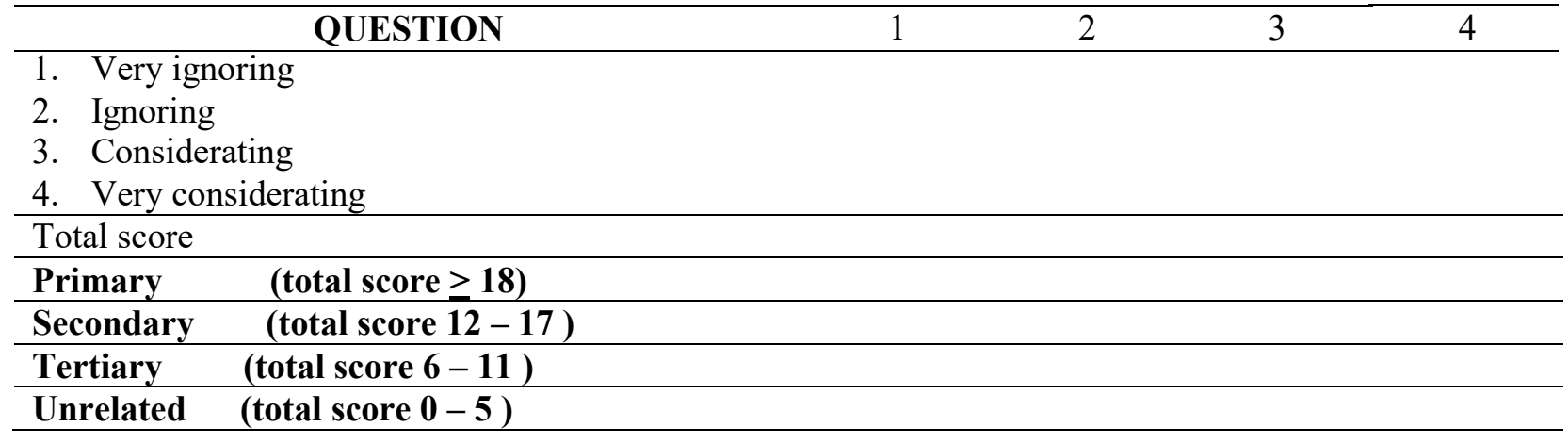

Third, organizations were classified into primary, secondary, and tertiary classes to estimate the number of organizations to be involved in the project. This process also aimed to manage the project's resources effectively and optimize the achievement of goals based on the reach of the project and the representation of people in the project. Assessment must be done on primary organizations first. If the project has more funds, then assessment continues to secondary and tertiary organizations. Results of this process can become a reference for the supra-village institutions in determining the empowerment target. Respondents chosen within the process were the village head, community leaders, and village officials. The indicators used to assess whether an organization has a good reach and represents the community or not are presented in Table 4.

Table 4. Aspects and Criteria for Choosing Organizations

\begin{tabular}{ll}
\hline \multicolumn{1}{c}{ ASPECTS } & \multicolumn{1}{c}{ CRITERIA } \\
\hline \multirow{2}{*}{ Reach } & Area managed \\
\cline { 2 - 2 } Representation & Personnel \\
\cline { 2 - 2 } & Political representation \\
\cline { 2 - 2 } & Functional representation \\
\cline { 2 - 2 } & Number of members \\
\hline
\end{tabular}

These aspects and criteria are then elaborated into questionnaire items as presented in Table 5.

Table 5. Form to Assess Priorities of Organizations

\begin{tabular}{|c|c|c|c|c|}
\hline \multirow{2}{*}{ QUESTIONS } & \multirow[b]{2}{*}{ INDICATORS } & \multicolumn{3}{|c|}{ ANSWERS } \\
\hline & & 12 & 3 & 4 \\
\hline $\begin{array}{l}\text { Does the organization work in one } \\
\text { (or more) of the following areas: } \\
\text { a. Forest conservation areas } \\
\text { b. Forest protected areas } \\
\text { c. Production forest } \\
\text { d. Watershed }\end{array}$ & $\begin{array}{ll}\text { 1. Yes } \\
\text { 2. No }\end{array}$ & & & \\
\hline $\begin{array}{l}\text { If the organization works in one } \\
\text { of those areas, how large is the } \\
\text { area it manages? }\end{array}$ & $\begin{array}{ll}\text { 1. } & 0-15 \mathrm{Ha} \\
\text { 2. } & 16-30 \mathrm{Ha} \\
\text { 3. } & 31-50 \mathrm{Ha} \\
\text { 4. } & >50 \mathrm{Ha} \\
\end{array}$ & & & \\
\hline $\begin{array}{l}\text { What is the level of organizational } \\
\text { sociocultural cohesion? }\end{array}$ & $\begin{array}{ll}\text { 1. } & \text { Very weak } \\
\text { 2. } & \text { Weak } \\
\text { 3. } & \text { Strong } \\
\text { 4. } & \text { Very strong } \\
\end{array}$ & & & \\
\hline $\begin{array}{l}\text { How is the level of the economic } \\
\text { welfare of members of the } \\
\text { organization? (based on official } \\
\text { statistical data) }\end{array}$ & $\begin{array}{l}\text { 1. Number of low-income families } \geq 80 \% \\
\text { 2. Number of low-income families } 50 \% \text { to } \\
79 \% \\
\text { 3. Number of low-income families up to } \\
49 \% \\
\text { 4. Number of low-income families }<25 \%\end{array}$ & & & \\
\hline
\end{tabular}


Table 5. Form to Assess Priorities of Organizations (advanced)

\begin{tabular}{|c|c|}
\hline $\begin{array}{l}\text { How many community leaders } \\
\text { (religious leaders, traditional } \\
\text { elders, cultural leaders, } k \text { kuncen, } \\
\text { juru kunci, etc.) are there? (If } \\
\text { there are any) }\end{array}$ & $\begin{array}{ll}\text { 1. } & 1 \\
\text { 2. } & 2-5 \\
\text { 3. } & 6-10 \\
\text { 4. } & \text { More than } 10\end{array}$ \\
\hline $\begin{array}{l}\text { What are the functions of areas } \\
\text { around the community? }\end{array}$ & $\begin{array}{l}\text { 1. Forest conservation areas } \\
\text { 2. Forest protected areas } \\
\text { 3. Production forest } \\
\text { 4. Watershed }\end{array}$ \\
\hline $\begin{array}{l}\text { How many are active and } \\
\text { productive members of the } \\
\text { organization involved in the work } \\
\text { related to forest areas and } \\
\text { watersheds? }\end{array}$ & $\begin{array}{ll}\text { 1. } & 5-20 \text { people } \\
\text { 2. } & 21 \text { to } 50 \text { people } \\
\text { 3. } & 51 \text { to } 100 \text { people } \\
4 . & >100 \text { people }\end{array}$ \\
\hline
\end{tabular}
watersheds?

Total Score

\begin{tabular}{l}
\hline High Priority/primary (Total Score 19-26) \\
\hline Priority/secondary (Total Score 11-18) \\
\hline Not Priority/tertiary (Total Score 1-10)
\end{tabular}

The assessment using the instrument in table 5 produced a list of organizations prioritized and not prioritized. This assessment would help management choose which organizations to work with, so group involvement covered both representation and orientation.

\section{c. Group Mentoring and Facilitation}

After the group selection finished, we reconstructed the mentoring and facilitation activities for the selected groups. This project deliberately placed initiatives on local and regional field assistants in the supervision of central management. Uniquely, the selected organizations were placed in four primary environments: the dynamics of the organization itself, the community and village political system, and the supra-village. Facilitators also took a strategic position by establishing relationships between groups, maintaining group dynamics, and recruiting voluntary facilitators to connect the interests of the group with parties from outside the village related to policy and market advocacy. The mentoring and facilitation process consisted of activities to strengthen social institutions related to forest and land rehabilitation. The activities were formulated in four stages of institutional development: (1) data collection and growth, (2) capacity building, (3) fostering independence, and (4) releasing. In detail, the process is summarized in Table 6.

Table 6. Development Stages of Local Organizations and the Indicators

\begin{tabular}{|c|c|c|c|c|}
\hline & $\begin{array}{lr}\text { Data } & \text { Collection } \\
\text { and } & \text { Initial } \\
\text { Growth } & (6 \\
\text { Months }) & \\
\end{array}$ & $\begin{array}{l}\text { Capacity } \\
\text { Building (1 Year) }\end{array}$ & $\begin{array}{l}\text { Fostering } \\
\text { Independence }(1 \\
\text { Year) }\end{array}$ & $\begin{array}{l}\text { Releasing } \\
\text { Months) }\end{array}$ \\
\hline $\begin{array}{l}\text { Leadership } \\
\text { Quality }\end{array}$ & $\begin{array}{l}\text { The capability of } \\
\text { social } \\
\text { organization } \\
\text { leaders in decision } \\
\text { making and } \\
\text { program } \\
\text { coordination can } \\
\text { be measured and is } \\
\text { documented }\end{array}$ & $\begin{array}{lr}\text { Leaders } & \text { of } \\
\text { registered social } \\
\text { organizations } \\
\text { learn to make } \\
\text { decisions and } \\
\text { coordinate } \\
\text { programs assisted } \\
\text { by forestry } \\
\text { technical } \\
\text { assistants }\end{array}$ & $\begin{array}{l}\text { Leaders } r \\
\text { registered social } \\
\text { organizations } \\
\text { learn to make } \\
\text { decisions and } \\
\text { coordinate } \\
\text { programs } \\
\text { supervised by } \\
\text { forestry technical } \\
\text { assistants }\end{array}$ & $\begin{array}{l}\text { Leaders of } \\
\text { registered social } \\
\text { organizations can } \\
\text { make decisions and } \\
\text { coordinate programs } \\
\text { independently } \\
\text { without supervision } \\
\text { from forestry } \\
\text { technical assistants }\end{array}$ \\
\hline
\end{tabular}


Table 6. Development Stages of Local Organizations and the Indicators (advanced)

\begin{tabular}{|c|c|c|c|c|}
\hline & $\begin{array}{l}\text { Data Collection } \\
\text { and Initial } \\
\text { Growth (6 } \\
\text { Months) } \\
\end{array}$ & $\begin{array}{l}\text { Capacity } \\
\text { Building (1 Year) }\end{array}$ & $\begin{array}{l}\text { Fostering } \\
\text { Independence (1 } \\
\text { Year) }\end{array}$ & $\begin{array}{l}\text { Releasing } \\
\text { Months) }\end{array}$ \\
\hline $\begin{array}{l}\text { Structure } \\
\text { Completeness } \\
\text { and Effectiveness }\end{array}$ & $\begin{array}{l}\text { The suitability of } \\
\text { the organizational } \\
\text { structure with } \\
\text { activities of Forest } \\
\text { and Land } \\
\text { Rehabilitation is } \\
\text { documented }\end{array}$ & $\begin{array}{l}\text { The structure and } \\
\text { functions of the } \\
\text { organization are } \\
\text { set to support the } \\
\text { effectiveness of } \\
\text { Forest and Land } \\
\text { Rehabilitation } \\
\text { under the } \\
\text { supervision of } \\
\text { forestry technical } \\
\text { assistants }\end{array}$ & $\begin{array}{l}\text { The structure and } \\
\text { functions of the } \\
\text { organization have } \\
\text { been able to } \\
\text { support the } \\
\text { effectiveness of } \\
\text { Forest and Land } \\
\text { Rehabilitation } \\
\text { under the } \\
\text { supervision of } \\
\text { forestry technical } \\
\text { assistants }\end{array}$ & $\begin{array}{l}\text { The structure and } \\
\text { functions of the } \\
\text { organization have } \\
\text { been able to support } \\
\text { the effectiveness of } \\
\text { Forest and Land } \\
\text { Rehabilitation } \\
\text { without supervision } \\
\text { from forestry } \\
\text { technical assistants }\end{array}$ \\
\hline $\begin{array}{l}\text { Strengthening } \\
\text { Organizational } \\
\text { Culture, Vision, } \\
\text { and Mission }\end{array}$ & $\begin{array}{l}\text { There must be } \\
\text { data on whether } \\
\text { the organizational } \\
\text { culture and vision } \\
\text { support the goals } \\
\text { and mission of } \\
\text { Forest and Land } \\
\text { Rehabilitation }\end{array}$ & $\begin{array}{l}\text { The organizational } \\
\text { culture, vision, } \\
\text { and mission } \\
\text { support the goals, } \\
\text { vision, and } \\
\text { mission of Forest } \\
\text { and Land } \\
\text { Rehabilitation } \\
\text { under the } \\
\text { supervision of } \\
\text { forestry technical } \\
\text { assistants }\end{array}$ & $\begin{array}{l}\text { The organizational } \\
\text { culture, vision, } \\
\text { and mission have } \\
\text { been firmly } \\
\text { supporting the } \\
\text { goals, vision, and } \\
\text { mission of Forest } \\
\text { and Land } \\
\text { Rehabilitation } \\
\text { under the } \\
\text { supervision of } \\
\text { forestry technical } \\
\text { assistants }\end{array}$ & $\begin{array}{l}\text { The organizational } \\
\text { culture, vision, and } \\
\text { mission have been } \\
\text { firmly supporting } \\
\text { the goals, vision, } \\
\text { and mission of } \\
\text { Forest and Land } \\
\text { Rehabilitation } \\
\text { without the } \\
\text { supervision from } \\
\text { forestry technical } \\
\text { assistants }\end{array}$ \\
\hline $\begin{array}{l}\text { Administrative } \\
\text { Completeness }\end{array}$ & $\begin{array}{l}\text { The administrative } \\
\text { system is mapped } \\
\text { to support Forest } \\
\text { and Land } \\
\text { Rehabilitation }\end{array}$ & $\begin{array}{l}\text { The administrative } \\
\text { system is complete } \\
\text { to support Forest } \\
\text { and Land } \\
\text { Rehabilitation } \\
\text { under the } \\
\text { supervision of } \\
\text { forestry technical } \\
\text { assistants }\end{array}$ & $\begin{array}{l}\text { The organization } \\
\text { has been able to } \\
\text { complete all its } \\
\text { administrative } \\
\text { systems to support } \\
\text { Forest and Land } \\
\text { Rehabilitation the } \\
\text { under of } \\
\text { supervision on } \\
\text { forestry technical } \\
\text { assistants }\end{array}$ & $\begin{array}{l}\text { The organization } \\
\text { has been able to } \\
\text { complete all its } \\
\text { administrative } \\
\text { systems to support } \\
\text { Forest and Land } \\
\text { Rehabilitation } \\
\text { independently } \\
\text { without supervision } \\
\text { from forestry } \\
\text { technical assistants }\end{array}$ \\
\hline $\begin{array}{l}\text { Supporting } \\
\text { Activities }\end{array}$ & $\begin{array}{l}\text { The programs of } \\
\text { the organization } \\
\text { are planned to } \\
\text { succeeding Forest } \\
\text { and Land } \\
\text { Rehabilitation } \\
\text { under super the } \\
\text { supervision of } \\
\text { forestry technical } \\
\text { assistants }\end{array}$ & $\begin{array}{l}\text { Some programs of } \\
\text { the organization } \\
\text { are directed } \\
\text { toward succeeding } \\
\text { Forest and Land } \\
\text { Rehabilitation } \\
\text { under the } \\
\text { supervision of } \\
\text { forestry technical } \\
\text { assistants }\end{array}$ & $\begin{array}{l}\text { Most programs of } \\
\text { the organization } \\
\text { are directed } \\
\text { toward succeeding } \\
\text { Forest and Land } \\
\text { Rehabilitation } \\
\text { under the } \\
\text { supervision of } \\
\text { forestry technical } \\
\text { assistants }\end{array}$ & $\begin{array}{l}\text { Most programs of } \\
\text { the organization are } \\
\text { directed toward } \\
\text { succeeding Forest } \\
\text { and } \\
\begin{array}{l}\text { Rehabilitation } \\
\text { without } \\
\text { supervision from } \\
\text { forestry technical } \\
\text { assistants }\end{array} \\
\end{array}$ \\
\hline
\end{tabular}




\section{d. The Process of Evaluation and Follow- Up Plan \\ Evaluation is the process of assessing} organizational performance based on five criteria: (1) leadership quality (30\%), (2) organizational structure effectiveness $(15 \%)$, (3) organizational culture (20\%), (4) administrative completeness $(20 \%)$, and (5) vision and mission $(15 \%)$. The weights were based on the justification of field assistants and academics experienced in management research and institutional dynamics. The detailed weighting could not be found in the project document, so we formulated it with colleagues and other researchers through focus group discussions. Organizational evaluation of these five aspects aimed to determine the quality of the organization. The results would help stakeholders in the project see how the organization could run according to its targets and objectives. The results could also measure the development potential and sustainability of the organization. Evaluation of organizational performance also affects the organizational follow-up of the project against the organizations around the project site. The respondents were sampled from group members, community leaders, village heads, and the general public. The assessment forms for the five organizational aspects and the total assessment are listed in Tables 7, 8, 9, 10, 11, and 12 .

Table 7. Leadership Quality Assessment Form

\begin{tabular}{llll}
\hline \multicolumn{1}{c}{ QUESTIONS } & \multicolumn{1}{c}{ INDICATORS } & ANSWERS \\
\hline Who has been & 1. & Only leaders \\
involved in the & 2. & Leaders and administrators \\
organization's & 3. & Managers \\
decision-making? & 4. & Leaders, administrators, managers \\
\hline When problems arise, & 1. & Based on the situation \\
who is the first person & 2. & Administrators \\
in charge of solving & 3. & Managers \\
the problems? & 4. & Members \\
\hline In implementing the & 1. & Done by the closest administrators \\
program, what is the & 2. & Based on the job description \\
proportion of task & 3. & Equal distribution \\
division among & 4. & According to the potential of \\
management? & & administrators \\
\hline What is the basis in & 1. & Leaders' prerogative rights \\
decision-making and & 2. & Suggestions from administrators \\
making policy? & 3. & Results of administrators' meetings \\
& 4. & Vision and mission of the \\
& & organization \\
\hline What kind of & 1. & Thank you \\
appreciation is given & 2. & Congratulation \\
to members who have & 3. & Announcement among \\
contributed to the & administrators \\
organization? & 4. & Written award \\
\hline Who is involved in & 1. & Done alone \\
running the program? & 2. & The closest administrators \\
& 3. & Managers \\
\hline Who has been giving & 4. & All administrators and managers \\
many aspirations and & 2. & Individual thoughts & The closest administrators \\
many suggestions? & 3. & Managers \\
\hline & 4. & All managers and administrators \\
\hline
\end{tabular}


Table 8. Organizational Structure Completeness and Effectiveness Form

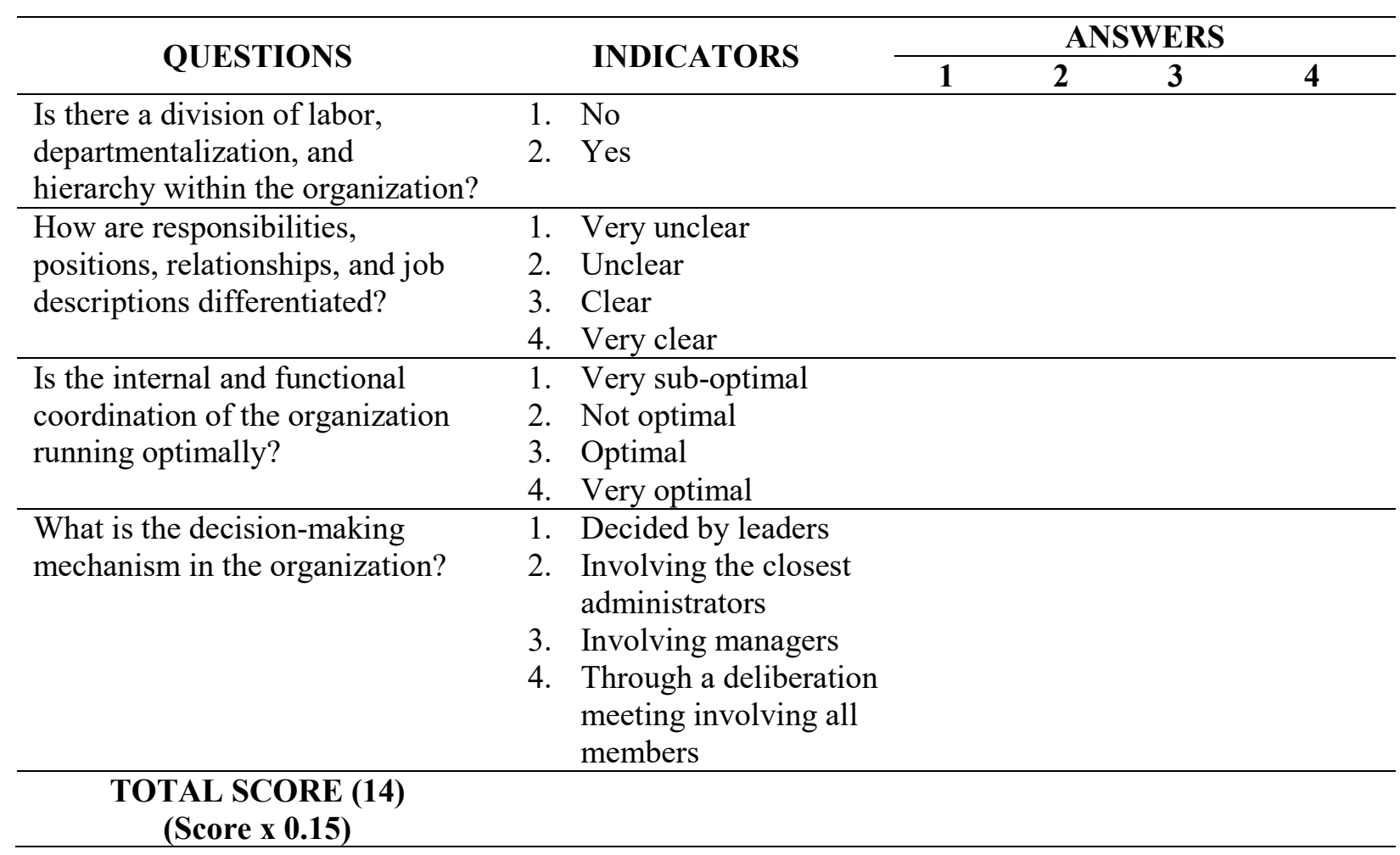

Table 9. Organizational Culture Dynamics Assessment Form

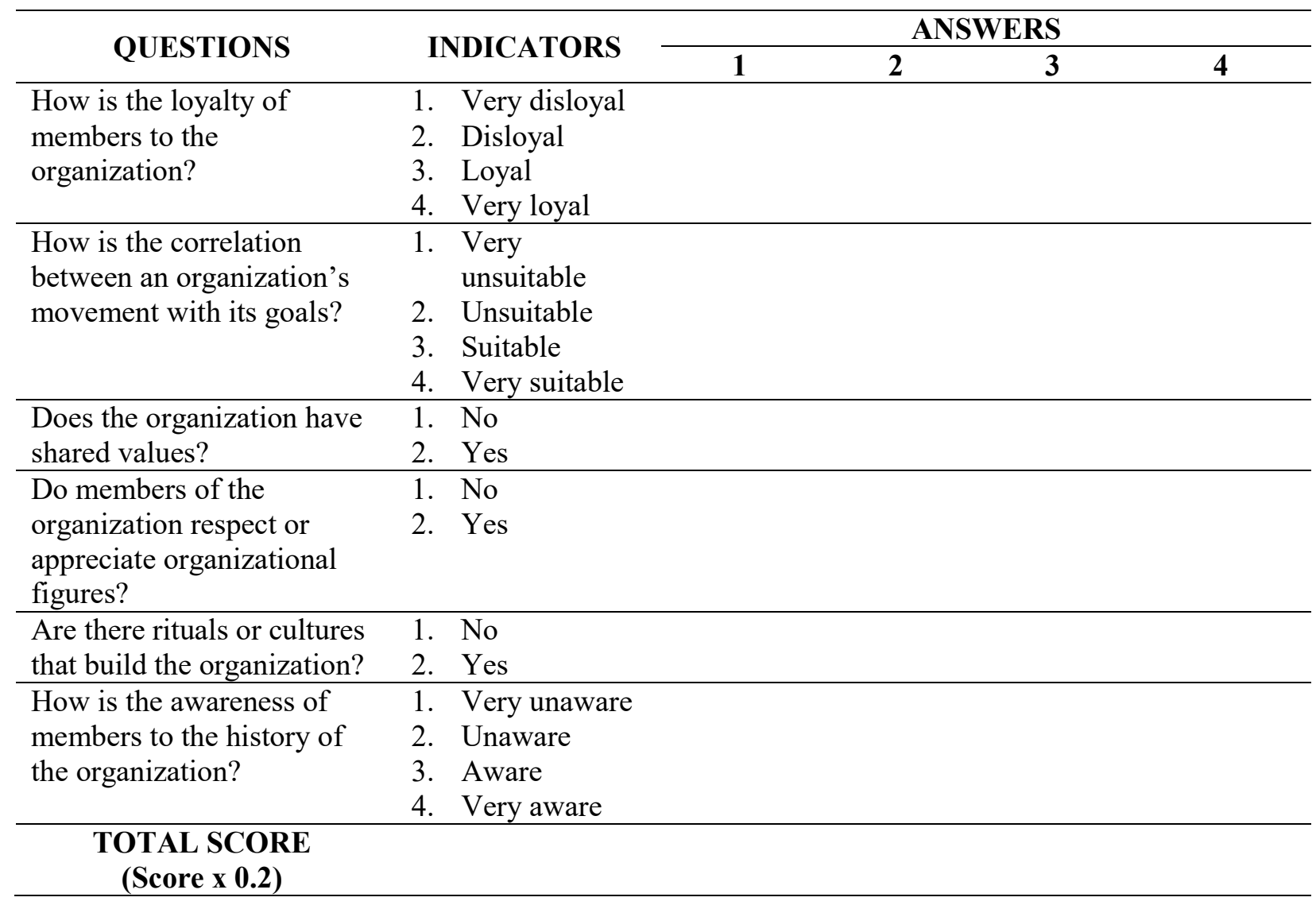


Table 10. Administrative Completeness and Effectiveness Assessment Form

\begin{tabular}{|c|c|c|c|c|}
\hline \multirow{2}{*}{ QUESTIONS } & \multirow{2}{*}{ INDICATORS } & \multicolumn{3}{|c|}{ ANSWERS } \\
\hline & & 1 & 3 & 4 \\
\hline $\begin{array}{l}\text { What is the level of } \\
\text { organizational productivity? } \\
\text { (measurable, meeting targets, } \\
\text { and sustainable) }\end{array}$ & $\begin{array}{l}\text { 1. Very unproductive } \\
\text { 2. Unproductive } \\
\text { 3. Productive } \\
\text { 4. Very productive }\end{array}$ & & & \\
\hline $\begin{array}{l}\text { Are there reports on member } \\
\text { satisfaction levels? }\end{array}$ & $\begin{array}{ll}\text { 1. } & \text { No } \\
\text { 2. } & \text { Yes } \\
\end{array}$ & & & \\
\hline $\begin{array}{l}\text { How does the organization } \\
\text { recognize organizational } \\
\text { problems and respond to } \\
\text { problem-solving? }\end{array}$ & $\begin{array}{ll}\text { 1. } & \text { Very unresponsive } \\
\text { 2. Unresponsive } \\
\text { 3. Responsive } \\
\text { 4. } \text { Very responsive }\end{array}$ & & & \\
\hline $\begin{array}{l}\text { Does the organization's } \\
\text { accountability report } \\
\text { conform to agreed } \\
\text { administrative principles? }\end{array}$ & $\begin{array}{ll}\text { 1. } & \text { Very unsuitable } \\
\text { 2. Unsuitable } \\
\text { 3. Suitable } \\
\text { 4. } \\
\end{array}$ & & & \\
\hline $\begin{array}{l}\text { Does the organization } \\
\text { routinely report Performance } \\
\text { and Budget Realization, } \\
\text { Cash Flow Statement, and } \\
\text { Accountability Statement? }\end{array}$ & $\begin{array}{ll}\text { 1. } & \text { Never } \\
\text { 2. } & \text { Sometimes } \\
\text { 3. } & \text { Often } \\
\text { 4. } & \text { Always }\end{array}$ & & & \\
\hline
\end{tabular}

Table 11. Vision and Mission Assessment Form




Table 12. Total Assessment Form

\begin{tabular}{lll}
\hline NO. & \multicolumn{1}{c}{ ASPECTS } & $\begin{array}{r}\text { TOTAL } \\
\text { SCORE }\end{array}$ \\
\hline 1. & Leadership \\
2. & Organizational Structure \\
3. & Organizational culture \\
4. & Administration \\
5. & Vision and Mission \\
\hline \multicolumn{3}{c}{ FINAL SCORE } \\
\hline Independent organization & $(>15)$ \\
Developed organization & $(11-15)$ \\
Undeveloped organization & $(6-10)$ \\
Very undeveloped & $(1-5)$ \\
\hline
\end{tabular}

After all the evaluation aspects were calculated, the quality of the organization would be revealed - the quality is divided into four categories: independent, developed, undeveloped, and very undeveloped. This category is the basis for involving organizations in a project.

\section{e. Trial on the Assessment Forms}

The formulated instruments were then used to measure the organizational performance of groups or organizations involved in the CCCD project, especially in Lampung. The organizational criteria used were: (1) independent, (2) developed, (3) undeveloped, and (4) very undeveloped. Organizations were measured based on five major aspects of (1) leadership quality, (2) structure completeness and effectiveness, (3) organizational culture, (4) administrative completeness, and (5) vision and mission. The higher the criterion an organization achieves, the more dynamic it is - it can be used as a basis for assessing whether assistance could improve the community's dynamics or not.

\section{f. Leadership Quality}

Leadership quality is one of the aspects affecting organizational success. From the 20 target groups, two had been identified to have all leadership quality criteria. The groups name were KTH Cirompang Jaya and Pokdarling Kusuma Sari. Eight groups were identified not to have the love criterion. Nine groups had to improve the aspect of empowerment in their leadership quality, and seven groups still did not have visionary leaders. Seven leaders in seven groups already showed humility. The eight identified groups still had to improve the trust of members towards their leaders - it would be necessary to conduct several evaluation activities and channel aspirations to regain trust from the members. Detail result of leadership quality of target groups illustrated in figure 5 .

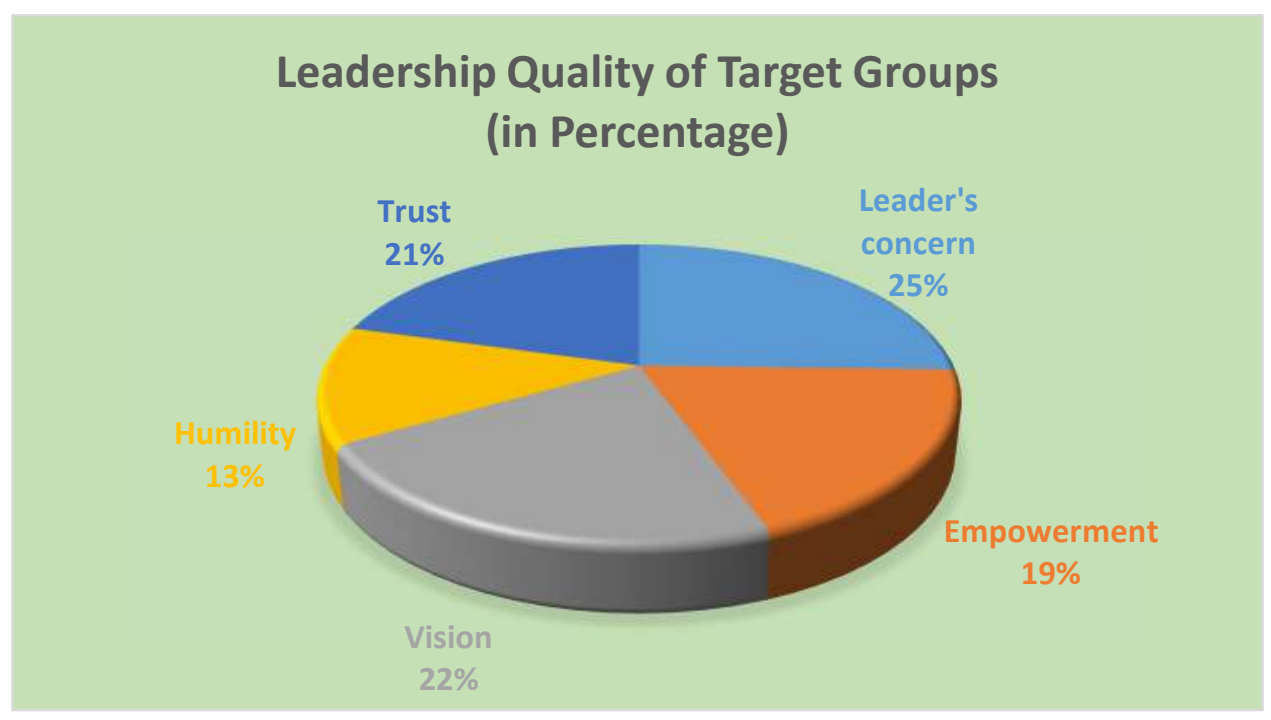

Figure 5. Leadership Quality Assessment Results

Figure 5. presents the overall assessment resulted from several indicators on leadership quality of the target groups. Future improvements must focus on the humility indicator since only $40 \%$ of the target groups could successfully implement humility. Leaders and managers must practice humility by respecting members and acknowledging members' contributions to the team.

Future improvement must also focus on empowerment. This indicator (empowerment) emphasizes cooperation or delegating authority to 
others and listening to recommendations from members and administrators. In other words, empowerment means that leaders protect and give members chances to be actively involved in achieving organizational goals. In addition, this indicator also lets all members have an essential role in the group so regeneration can run well.

\section{g. Structure Completeness and Effectiveness}

Observations confirmed that almost all 20 target groups had a complete and effective organizational structure. As such, this achievement must be maintained by educating all members and administrators to keep doing their job well based on their function so the organization can run well. Each member and administrator must be made aware of the importance of coordination and communication in managing the organization to achieve its vision and mission successfully. Detail organizational structure achievement of target groups illustrated in figure 6 .

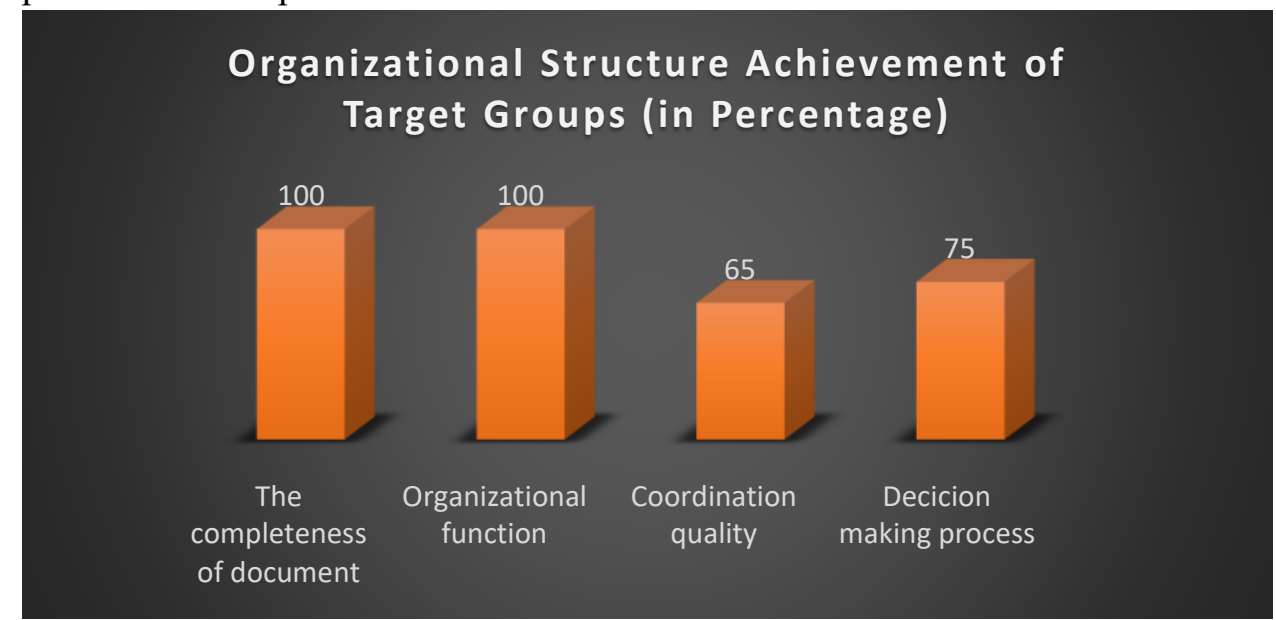

Figure 6. Organizational Structure Assessment Results

\section{h. Organizational Culture Dynamics}

We found one group, KTH Damar Kubang, from the 20 target groups that had to improve the loyalty of its members. Seven groups were identified as not having an organizational culture that could direct the members to support and realize organizational goals. Six organizations were found to not yet having shared values and strong organizational culture and characters. Twelve target groups had organizational figures or founding fathers they appreciated. Seven target groups did not have rituals that helped to build the organization. Thirteen groups had to improve their awareness of the history of their organization. Detail of organizational culture assessment results illustrated in the figure 7 .

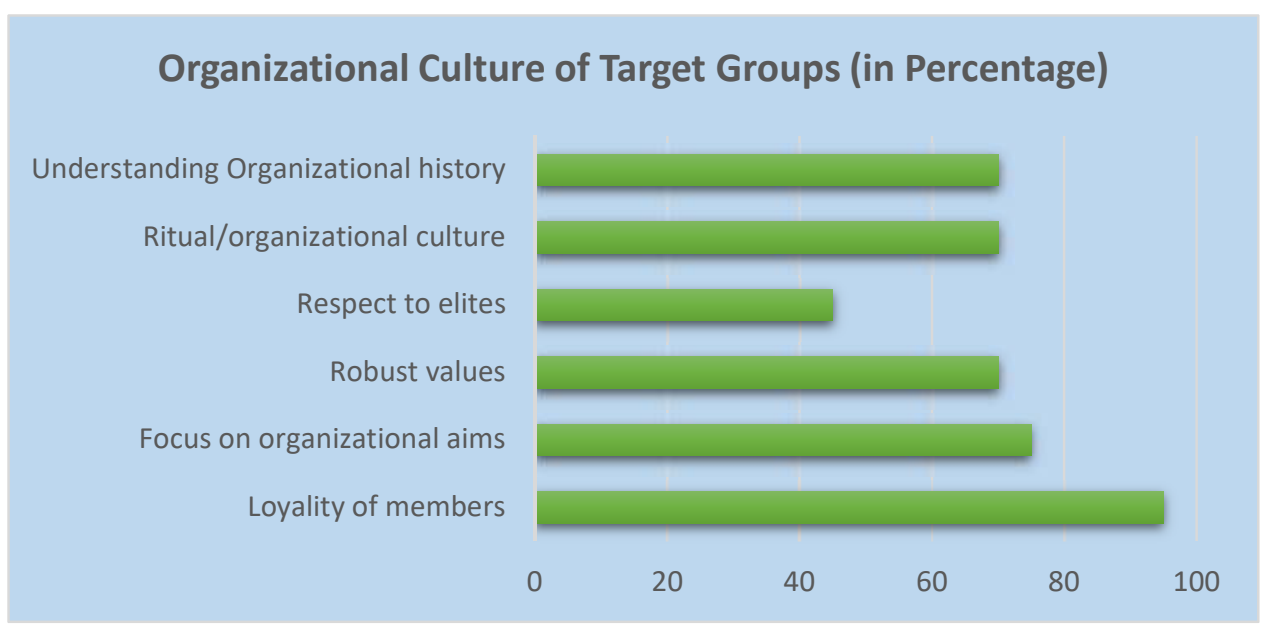

Figure 7. Organizational Culture Assessment Results 
In general, the organizational culture was running as it had to in the target group, but some things can be improved. Figure 6 shows that none of the indicators reaches $100 \%$. Appreciation for organizational figures needs improvement to create a comfortable environment for all members. In addition, this appreciation will help members and administrators be the best and show the best achievement in the group.

\section{i. Administrative Completeness}

The administration is one factor determining an organization's success in realizing its vision and mission. Based on our observations of 20 groups, only two groups met all administrative performance indicators, namely KTH Maju Tani and KWTH Mawar Jaya. These groups had not performed their administrative and financial matters well. Detail percentage of the administrative and financial completeness of the groups target illustrated in figure 8 .

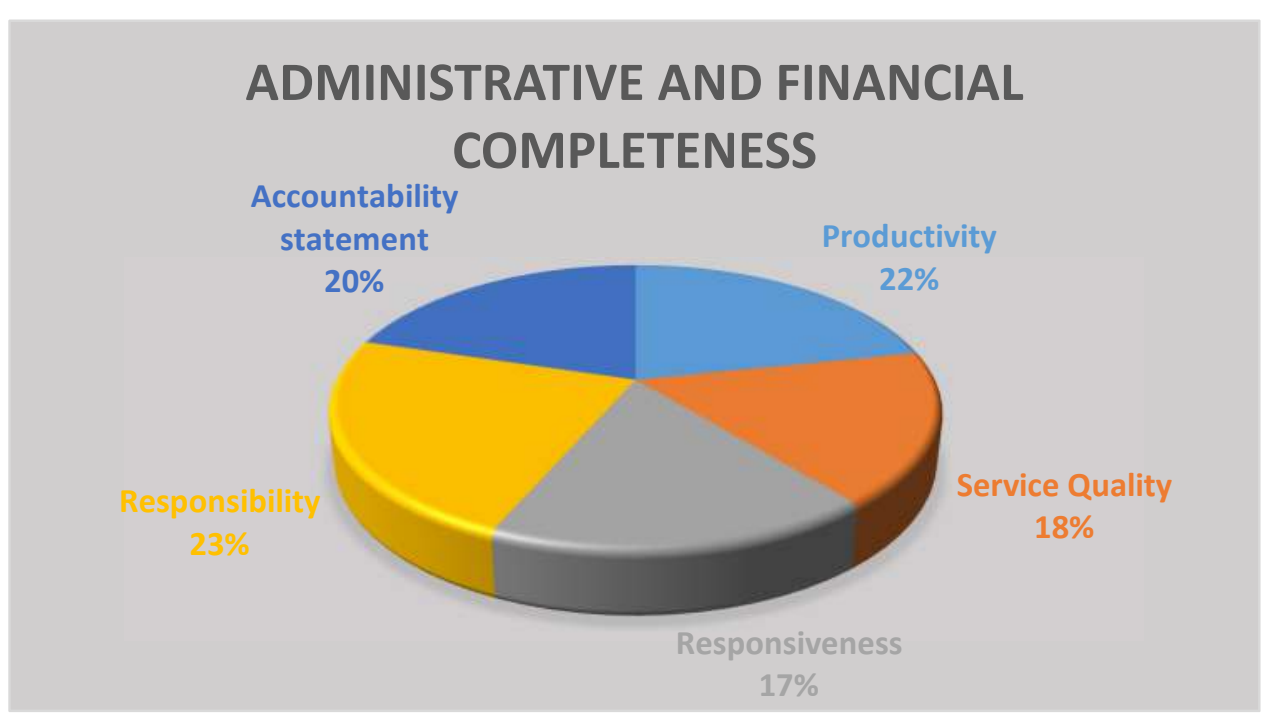

Figure 8. The Administrative and Financial Completeness

\section{j. $\quad$ Visionary of Vision and Mission}

Two target groups had all the criteria, namely KWTH Melati Jaya and Pokdarling Kusuma Sari. KTH Mekar Jaya I and KWTH Berkah Jaya did not have vision and mission or clear goals. Eight groups had to improve their vision and mission, and only seven groups succeeded in growing enthusiasm among their members. Four groups had a vision and mission, yet their members found it hard to understand. Only two groups could not fulfill the criteria regarding accuracy and measurability, namely KTH Wana Jaya and KTH Damar Kubang.

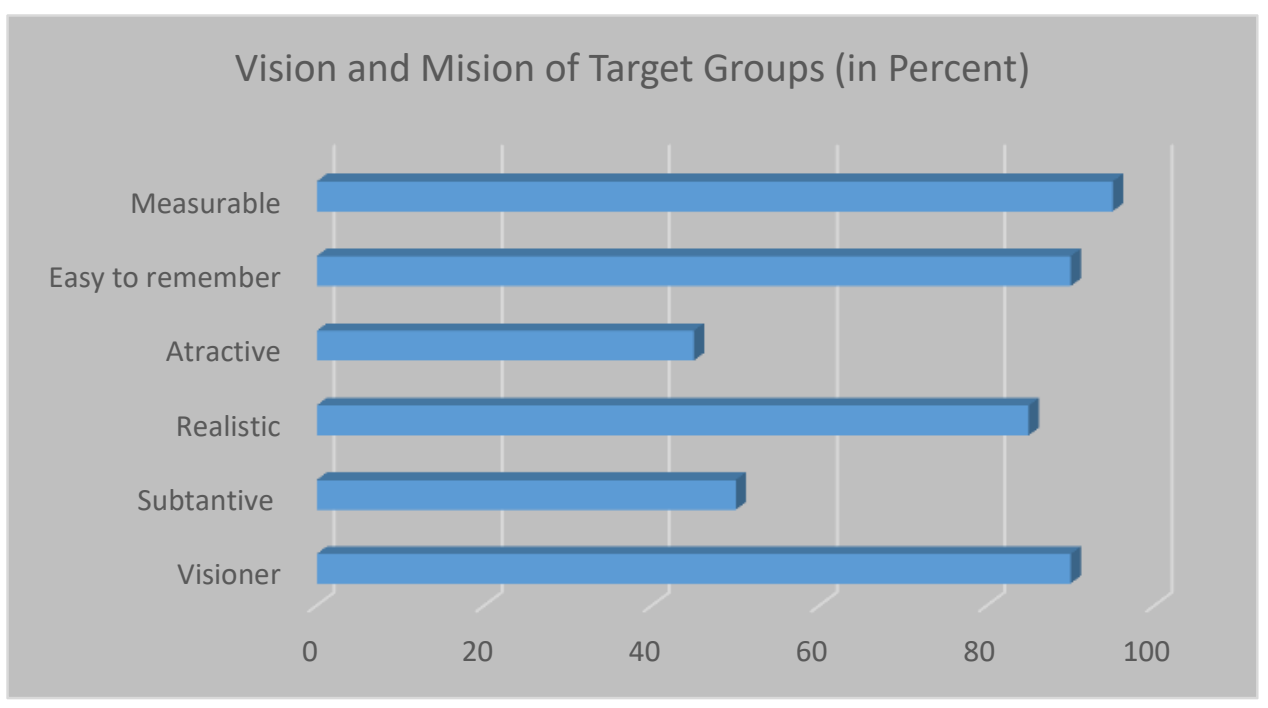

Figure 9. Vision and Mission Assessment Results 
Figure 9. shows the assessment results for all groups in each indicator on vision and mission. From the six indicators, $90 \%$ of the groups have been identified as having a visionary and measurable vision and mission. In addition, $85 \%$ of the total target groups are considered to have realistic goals. Related to easily remembered vision and mission statements, $80 \%$ of groups have met the indicator. Then, $60 \%$ of the groups had a substantive vision and mission. Related to attractiveness, only $35 \%$ of the group is considered to have an attractive vision and mission. The data shows inequality, especially in the attractiveness indicator. It shows that the groups or organizations need activities, movement patterns, or programs that can systemically stimulate understanding, experience, or even change in their vision and mission.

The group approach to the CCCD project in Indonesia is theoretically directed at a substantive approach. It means that, from the beginning, identification is made on organizations directly linked with conservation activities, such as forest farmer groups and tourism groups that manage conservation areas (Yao et al., 2020). Other groups involved later are recommendations from consultants recruited by the project and suggestions from village heads and field assistants. This non-standard process indicates that this project provides an opportunity for local officials to select new groups to be involved in the project-not only in direct connection with the project but also in its dynamics. The emphasis on group performance and direct linkage to conservation activities and the lack of standardized group selection procedures demonstrate the project's commitment to taking a substantive approach rather than a procedural approach.

Our reconstruction involved all groups at the beginning and end of the project-it helped show each group's position towards the project. After the primary and secondary organizations were selected, they were classified into highly prioritized, prioritized, and not prioritized organizations in the program. From all the groups evaluated, it was clear that not all groups had a close relationship with the success of the CCCD project. It happened because the activities of each member did not always have a direct relationship with the activities they previously did, so they had no specific functions in the project. As such, we evaluated the situation and concluded the four group categories, namely (1) primary, (2) secondary, (3) tertiary, and (4) unrelated groups. It means assistance must be prioritized in groups with closer linkage to the project. The categories can also prevent an incompetent group from entering a project - a group without direct linkage to the project and needed competence. The results of our evaluation are presented in Figure 10.

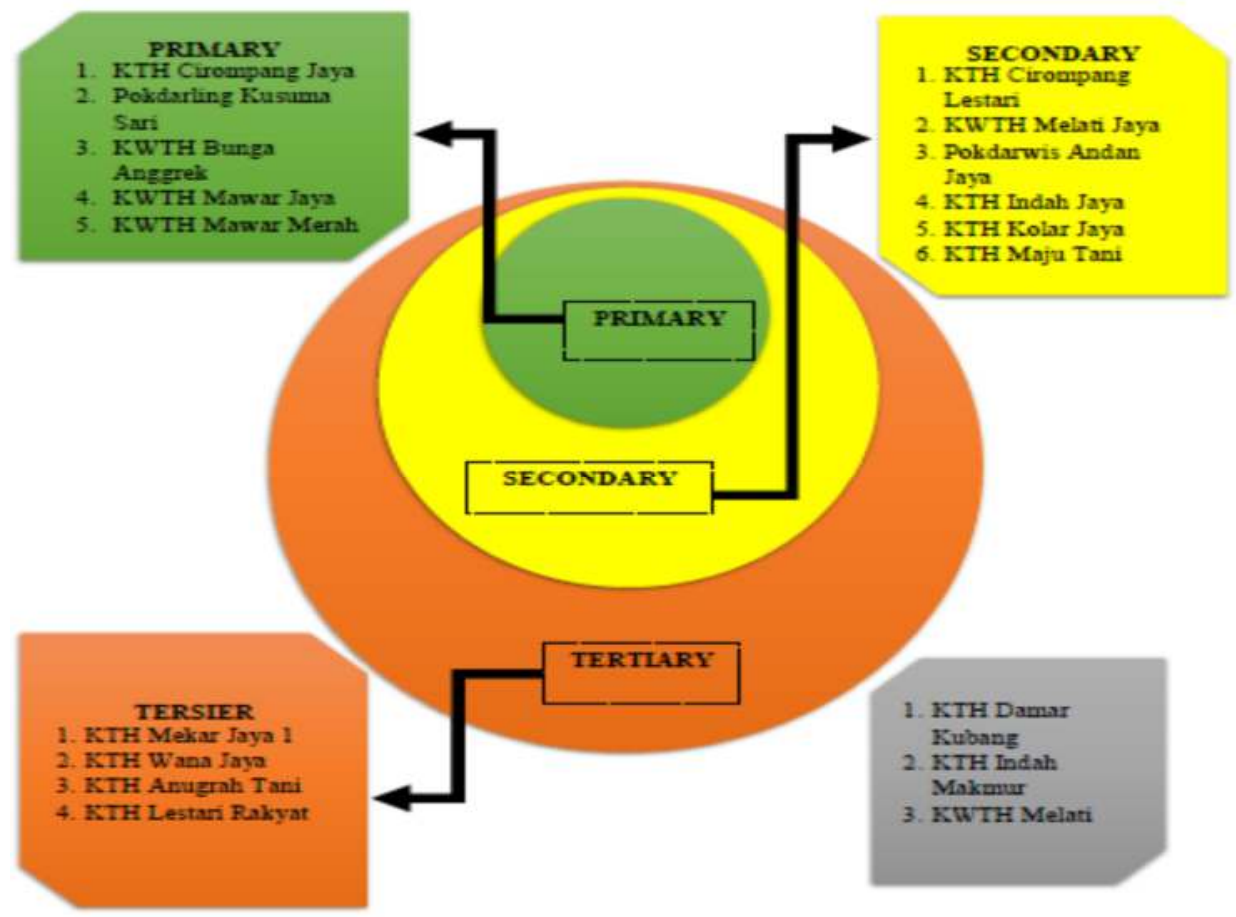

Figure 10. Positions of Social Organizations 
Our reconstruction confirmed that project managers understood that group involvement and selection based on group performance did not significantly impact the project goals. Therefore, they combined administrative and substantive approaches, and during our study, assessment on aspects like the close relationship between group activities and conservation activities became a major consideration. Besides, the existence of divisions that focused on nature conservation was also one important consideration in selecting groups in addition to the group's vision and mission that supported the project goals. The hybrid approach combining substance and procedure was chosen by project managers by developing an instrument that accommodated the two components in selecting groups to be involved.

Table 13. Categories of Organizations Involved in CCCD Project

\begin{tabular}{|c|c|c|c|c|c|}
\hline \multirow{2}{*}{$\begin{array}{c}\text { Status of } \\
\text { organization }\end{array}$} & \multicolumn{2}{|c|}{ Organization coverage area } & \multicolumn{3}{|c|}{ Representation of organization } \\
\hline & $\begin{array}{c}\text { Area } \\
\text { managed }\end{array}$ & Personnel & $\begin{array}{c}\text { Political } \\
\text { representation }\end{array}$ & $\begin{array}{c}\text { Functional } \\
\text { representation }\end{array}$ & $\begin{array}{c}\text { Number of } \\
\text { members }\end{array}$ \\
\hline Primary & $\begin{array}{l}\text { Wide } \\
\text { area }\end{array}$ & $\begin{array}{l}\text { If the members are } \\
\text { many and scattered } \\
\text { throughout the work } \\
\text { area of the } \\
\text { organization }\end{array}$ & $\begin{array}{l}\text { It has influence } \\
\text { on decision } \\
\text { making at } \\
\text { village level }\end{array}$ & $\begin{array}{l}\text { Conservation is } \\
\text { the main goal } \\
\text { of the } \\
\text { organization }\end{array}$ & $\begin{array}{l}\text { Large more } \\
\text { than } 100 \\
\text { members }\end{array}$ \\
\hline Secondary & $\begin{array}{l}\text { Moderate } \\
\text { area }\end{array}$ & $\begin{array}{l}\text { If the members are } \\
\text { concentrated in a } \\
\text { certain area but there } \\
\text { are many. }\end{array}$ & $\begin{array}{l}\text { It has less } \\
\text { influence on } \\
\text { decision making } \\
\text { at village level }\end{array}$ & $\begin{array}{l}\text { Conservation is } \\
\text { secondary goal } \\
\text { of the } \\
\text { organization }\end{array}$ & $\begin{array}{l}\text { Moderate } 50 \\
\text { to } 100 \\
\text { members }\end{array}$ \\
\hline Tertiary & $\begin{array}{l}\text { Narrow } \\
\text { area }\end{array}$ & $\begin{array}{l}\text { If the members are } \\
\text { concentrated in a } \\
\text { certain area but there } \\
\text { are many. }\end{array}$ & $\begin{array}{l}\text { It does not } \\
\text { influence on } \\
\text { decision making } \\
\text { at village level }\end{array}$ & $\begin{array}{l}\text { Conservation is } \\
\text { not the goal of } \\
\text { the } \\
\text { organization }\end{array}$ & $\begin{array}{lr}\text { Small } & \text { less } \\
\text { than } & 50 \\
\text { people } & \end{array}$ \\
\hline
\end{tabular}

Sources: Primary data processed (2021)

\section{Conclusion}

Findings confirmed that the substantive approach was more effective in reaching project goals, yet field assistants found it hard to practice. Thus, an instrument measuring the suitability of organizational procedure, performance, vision, and mission with project goals would be crucial. Based on our reconstruction of the CCCD project, three processes were identified in group involvement in the project. The first process was the identification and selection of groups or organizations. It involved three sub-processes: (1) collecting data, (2) mapping the organization's orientation, and (3) selecting organizations. The second process was mentoring and facilitation. This process strengthened the social organizations that had a direct relationship with the forest and land rehabilitation and was done in four stages of organizational development: (1) data collection and growth, (2) capacity building, (3) fostering independence, and (4) releasing. The third process was evaluation and follow-up plan based on five criteria: (1) leadership quality (30\%), (2) organizational structure effectiveness $(15 \%)$, (3) organizational culture (20\%), (4) administrative completeness $(20 \%)$, and (5) vision and mission $(15 \%)$. The weights were based on the justification of field assistants and academics experienced in management research and institutional dynamics.

Our findings also revealed that the development of local organizations or groups within a certain project was not only about the performance and relationship the group had with the project, but it was also a form of social representation. The groups involved must represent the interest of the community on the resources managed to gain legitimacy from the community. Thus, the groups involved must have such clear positioning within the social system for easied activity formulation. The organizational form and design developed within the CCCD project after the reconstruction is schematically presented in Figure 9. 


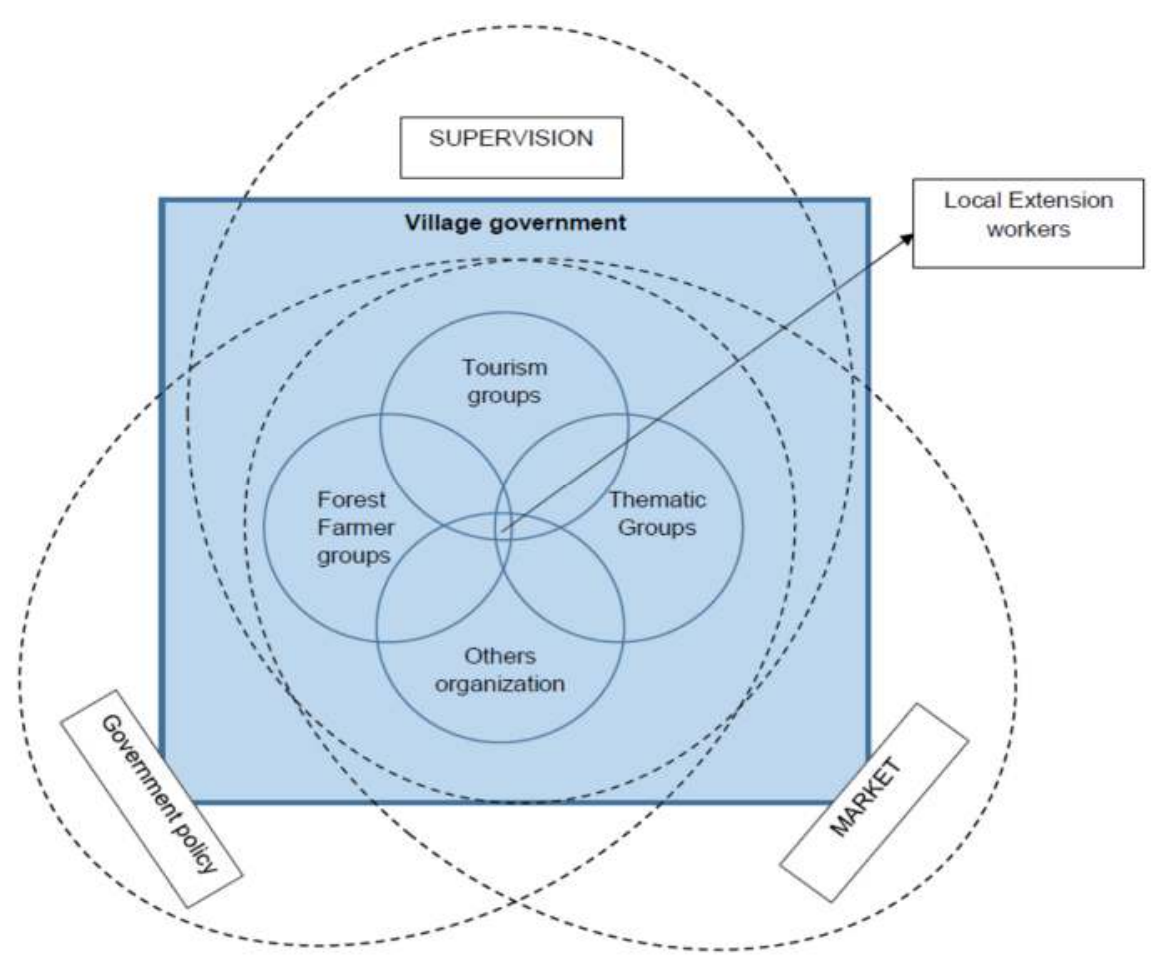

Figure 9. Organizational Design for the CCCD Local Project

Based on findings, the lesson learned from this CCCD project was as follows. First, the process of organizational development must be managed specifically separated from the technical activities as a project and organizational empowerment as an activity attached to all the technical activities. Second, group criteria must not be taken as a rigid standard; the criteria are simply an indication that a group or organization has entered certain levels. Third, if a group scores close to the upper or lower threshold, an assessment must be considered qualitatively to put the group at the upper or lower level. Organizational development must be detailed during implementation because organizational development is closely related to field conditions. Similar to organizational development, there must not be a rigid limit between one stage and another, so qualitative assessment is still needed. The process must be completed with consideration on environmental carrying capacity so that it does not focus on mere institutional dynamics but also other aspects of institutional development.

\section{References}

Abdul-Rahaman, A., \& Abdulai, A. (2018). Do farmer groups impact on farm yield and efficiency of smallholder farmers?
Evidence from rice farmers in northern Ghana. Food Policy, 81, 95-105.

Asbari, M. (2020). Is Transformational Leadership Suitable for Future Organizational Needs?. International Journal of Social, Policy and Law, 1(1), 5155.

Barbuto, JE. and Wheeler DW. 2006. Scale development and construct clarification of servant leadership. Group \& Organization Management

Barham, J., \& Chitemi, C. (2009). Collective action initiatives to improve marketing performance: Lessons from farmer groups in Tanzania. Food policy, 34(1), 53-59.

Bulkis, S., Arsyad, M., Amrullah, A., \& Viantika, N. M. (2018, May). Role of farmer group institutions in increasing farm production and household food security. In IOP Conference Series: Earth and Environmental Science (Vol. 157, No. 1, p. 012062). IOP Publishing.

Chambers, R. (1983). Rural Development-Putting the Last First: Longman Scientific and Technical. Harlow, UK. 
Chatelain, G., Hille, S. L., Sander, D., Patel, M., Hahnel, U. J. J., \& Brosch, T. (2018). Feel good, stay green: positive effect promotes pro-environmental behaviors and mitigates compensatory "mental bookkeeping" effects. Journal of environmental psychology, 56, 3-11.

Dennis, R. 2004. Development of the Servant Leadership Assessment Instrument. Leadership \& Organization Development Journal.

Diiro, G. M., Seymour, G., Kassie, M., Muricho, G., \& Muriithi, B. W. (2018). Women's empowerment in agriculture and agricultural productivity: Evidence from rural maize farmer households in western Kenya. PloS one, 13(5), e0197995.

Dutta, B. (2015). Rural Development through Self-Help Groups (SHGs): an Overview. Indian Journal of Applied Research, 5(4), 70-8.

do Nascimento, N. M., Cabero, M. M. M., \& Valentim, M. L. P. (2021). Information and Document Flow in Organizational Environments. In Role of Information Science in a Complex Society (pp. 202223). IGI Global.

Dwiyanto, Agus. 2006. Mewujudkan Good Governance Melalui Pelayanan Publik. Yogyakarta: Gadjah Mada University Press.

Hendren, K., Luo, Q. E., \& Pandey, S. K. (2018). The state of mixed methods research in public administration and public policy. Public Administration Review, 78(6), 904-916.

Hoffmann, V., Rao, V., Surendra, V., \& Datta, U. (2021). Relief from usury: Impact of a selfhelp group lending program in rural India. Journal of Development Economics, 148, 102567.

Kalkman, J. P., \& de Waard, E. J. (2017). Interorganizational disaster management projects: Finding the middle way between trust and control. International Journal of Project Management, 35(5), 889-899.
Grossmann, R., Scala, K., \& Bauer, G. (2018). Systemic Organization Development. IAP.

Kalra, R. K., Anil, B., Tonts, M., \& Siddique, K. H. M. (2013). Self-help groups in Indian agriculture: a case study of farmer groups in Punjab, Northern India. Agroecology and sustainable food systems, 37(5), 509-530.

Lubis, F. R., \& Hanum, F. (2020, December). Organizational culture. In 2nd Yogyakarta international conference on educational management/administration and pedagogy (YICEMAP 2019). Atlantis Press (pp. 8891).

Mariyono, J. (2015). Green revolution-and wetland-linked technological change of rice agriculture in Indonesia. Management of Environmental Quality: An International Journal.

Muralidharan, E., \& Pathak, S. (2018). Sustainability, transformational leadership, and social entrepreneurship. Sustainability, 10(2), 567.

Mosher, A. T. (1969). Creating a progressive rural structure. Creating a progressive rural structure. New York: Agric. Dev. Coun.

Mwaura, F. (2014). Effect of farmer group membership on agricultural technology adoption and crop productivity in Uganda. African Crop Science Journal, 22, 917-927.

Ochieng, J., Knerr, B., Owuor, G., \& Ouma, E. (2018). Strengthening collective action to improve marketing performance: evidence from farmer groups in Central Africa. The Journal of Agricultural Education and Extension, 24(2), 169-189.

Oxby, C. (1983). "Farmer groups" in rural areas of the Third World. Community Development Journal, 18(1), 50-59.

Parris, D. L., \& Peachey, J. W. (2013). A systematic literature review of servant leadership theory in organizational contexts. Journal of Business Ethics, 113(3), 377-393. 
Patterson, K. (2003). Servant leadership: A theoretical model. Dissertation Abstracts International, 64(02), 570. (UMI No. 3082719).

Rey, C., \& Bastons, M. (2018). Three dimensions of effective mission implementation. Long Range Planning, 51(4), 580-585.

Richard, P. J., Devinney, T. M., Yip, G. S., \& Johnson, G. (2009). Measuring organizational performance: Towards methodological best practice. Journal of management, 35(3), 718-804.

Rosset, P., Collins, J., \& Lappé, F. M. (2000). Lessons from the green revolution. Third World Resurgence, 11-14.

Rustinsyah, R. (2019). The significance of social relations in rural development: A case study of a beef-cattle farmer group in Indonesia. Journal of Co-operative Organization and Management, 7(2), 100088.

Singh, S. K., Del Giudice, M., Chierici, R., \& Graziano, D. (2020). Green innovation and environmental performance: The role of green transformational leadership and green human resource management. Technological Forecasting and Social Change, 150, 119762.

Spears, L. (2002). Character and Servant Leadership: Ten Characteristics of Effective, Caring Leaders. The Journal of Virtues \& Leadership

Wibisono., (2006), Visi dan Misi Perusahaan, http://utomokdl.blogspot.com/

2007/11/merumuskan-visi-dan-misi.html.

Diakses 4 Oktober 2021

Yao, X., He, J., \& Bao, C. (2020). Public participation modes in China's environmental impact assessment process: An analytical framework based on participation extent and conflict level. Environmental Impact Assessment Review, 84, 106400. 